\title{
Kompetensi Komunikasi Antarbudaya Siswa Sekolah Menengah Atas
}

\section{Intercultural Communication Competence of Senior High School Students}

\author{
Moulita \\ Ilmu Komunikasi, Fakultas Ilmu Sosial dan Ilmu Politik, Universitas Sumatera Utara,Indonesia \\ *Coresponding Email: moulita12@gmail.com
}

\begin{abstract}
Abstrak
Penelitian ini dimaksudkan untuk melihat bagaimana kompetensi komunikasi antarbudaya yang dimiliki oleh para siswa di SMA Sultan Iskandar Muda Medan. Melalui pendekatan kualitatif dengan menerapkan metode studi kasus, permasalahan dalam penelitan ini akan dijawab dengan menggunakan satu model kompetensi komunikasi antarbudaya yang terdiri dari tiga komponen, yaitu: kognitif, afektif, dan perilaku. Tingkat kecakapan yang paling baik sesuai konsep yang diajukan, ditemukan pada subjek atau individu yang mempunyai kesadaran atau pengetahuan tentang budaya sendiri dan orang lain, konsep diri yang tinggi, keterbukaan pikiran, tidak menghakimi orang lain, serta mampu menampilkan relaksasi sosial, manajemen interaksi, dan keterampilan sosial yang baik dalam menjalin interaksi antarbudaya. Dalam penelitian ini kecakapan paling baik dimiliki oleh Informan 1 dan Informan 6.
\end{abstract}

Kata Kunci: Kompetensi Komunikasi Antarbudaya, Siswa, Sekolah Menengah Atas

\begin{abstract}
The objective of the research is to find out how the intercultural communication competence possessed by the students of Sultan Iskandar Muda High School Medan. Through qualitative approach by applying case study method, the problem in this research will be answered by using an intercultural communication competence which consists of three components: affective, cognitive, and behavioral. The best level of proficiency according to the concept proposed, found in subjects or individuals who have awareness or knowledge of their own culture and others, high self-concept, openness of mind, not judging others, and able to display social relaxation, interaction management, and good social skills in establishing intercultural interactions. In this study the skills are best possessed by Informant 1 and Informant 6.
\end{abstract}

Keywords: Intercultural Communication Competence, Students, Senior High School

How to Cite: Moulita. (2019). Kompetensi Komunikasi Antarbudaya Siswa Sekolah Menengah Atas. Jurnal Simbolika. 5 (1): 23-34 


\section{PENDAHULUAN}

Cakap atau kompeten dalam berkomunikasi antarbudaya berarti bahwa seseorang harus mampu mengatasi masalah yang ada, termasuk rasa khawatir ketika berinteraksi dengan individu dari budaya yang berbeda.

Kompetensi komunikasi antarbudaya (intercultural communication competence/ICC) adalah kemampuan untuk menjalankan berbagai perilaku komunikasi dengan efektif (effective) dan sesuai (appropriate), yang dapat memadukan identitas budaya yang satu dengan yang lain atau berbagai identitas dalam lingkungan kebudayaan yang berbeda-beda (Chen dan Starosta, 1996).

Saat ini, ICC menjadi perhatian baik secara internasional maupun di antara budaya domestik yang berada di negara multikultural. Namun perlu terus dikembangkan tidak hanya pada tataran teori saja melainkan sampai pada tahapan praktis yang dapat membantu orang lain sukses dalam pertemuan antarbudaya mereka (Koester \& Lustig, 2015).

Sejak 2015 beberapa akademisi mengevaluasi teori, model, dan metode kajian ICC (Peng \& Wu (2019); Yaros, M., Lukic \& Gruber (2018); Martin 2015; Lieberman \& Gamst (2015); Kealey (2015); Collier (2015), Martin (2015)) umpamanya, menjelaskan bahwa sebagian besar model/teori ICC selalu mempunyai pola "ABC" (pengaruh, perilaku, dan kognitif/pengetahuan) yang dapat digambarkan sebagai berikut: dua (atau lebih) individu yang memiliki motivasi, ditandai oleh perbedaan budaya mereka, melakukan interaksi antarbudaya melalui akomodasi dan saling menampilkan ABC, mencapai makna bersama, saling pengertian, dan sampai pada hubungan yang saling memuaskan.

Oleh itu, Yep's (dikutip dalam Martin, J. N, 2015) menyarankan perlunya kajian ICC dengan konseptualisasi budaya yang bersifat dinamis, saling berkontestasi, identitas budaya ganda, dan interaksi antarbudaya.

Selain itu, Lieberman \& Gamst (2015) menjelaskan seluruh proses komunikasi lintas budaya selalu berkaitan dengan konteks. Komunikasi lintas budaya mencakup banyak variabel termasuk: 1) latarbelakang orang yang berinteraksi (etnis minoritas/ras, agama, imigran, pengungsi, buruh migran, pelancong bisnis; 2) konteks interaksi (perjalanan/belajar di luar negeri; 3) sosiodemografi (misalnya, pekerjaan/ pendidikan), dan kesamaan (misalnya, linguistik atau budaya; 4) aspek durasi interaksi. Dengan konteks ini, kompetensi komunikasi antarbudaya memengaruhi efektivitas dan kesesuaian dengan tujuan 
menghasilkan adaptasi lintas budaya yang diinginkan (yaitu mengubah perilaku seseorang karena lingkungan) dan penyesuaian (yaitu, kondisi suasana hati seperti harga diri, stres, dan kepercayaan diri yang menyertai penyesuaian).

Menurut Chen (2014) individu yang kompeten dalam konteks antarbudaya harus memiliki kapasitas, antara lain: mengetahui nilai-nilai budayanya sendiri dan orang lain, menunjukkan perasaan positif, menghargai, dan bahkan menerima perbedaan-perbedaan budaya serta mampu bertingkah laku dengan pantas dan sesuai dalam konteks interaksi antarbudaya.

Orang tersebut mestilah sensitif terhadap perasaan dan pikiran orang lain, mengungkapkan rasa hormat dan hal positif bagi orang lain, dan tidak menghakimi. Pada intinya, ia harus memiliki sifat percaya diri, mampu mengambil inisiatif, tenang dalam masamasa kecemasan dan ambigu, serta tidak kaku. Individu secara teknis atau profesional adalah orang yang cakap.

ICC juga dijelaskan oleh Wiseman (dikutip dalam Penbek, Yurdakul, \& Cerit, 2009) sebagai penyatuan pengetahuan, keterampilan, dan motivasi yang diperlukan untuk berinteraksi dengan efektif dan sesuai dengan individuindividu dari budaya yang berbeda.

Selain itu, Kim (dikutip dalam Williams, 2005) merangkum ke dalam satu hipotesis bahwa kompetensi komunikasi antarbudaya merupakan hasil kemampuan adaptasi, yaitu kemampuan seseorang untuk menyesuaikan beberapa cara atau adat lama suatu budaya, di mana ia akan mempelajari dan menyesuaikan diri dengan adat yang baru, serta secara kreatif dapat menemukan cara untuk mengatur dinamika dari perbedaan budaya atau ketidakakraban, gaya antarkelompok, dan pengendalian atas tekanan. Kim (dalam Williams, 2005) juga menuturkan bahwa terdapat tiga dimensi yang berkaitan dengan konsep kompetensi komunikasi antarbudaya, antara lain: (1) dimensi kognitif, yaitu mekanisme penafsiran seseorang atau struktur yang memberikan makna terhadap pesan, (2) dimensi afektif, yang merujuk pada motivasi seseorang atau keinginannya untuk menjembatani kebudayaan yang berbeda, dan (3) dimensi perilaku, ialah kemampuan seseorang untuk bersikap fleksibel serta pandai dalam menggunakan keahlian kognitif dan afektif yang dimilikinya.

Sumber lain juga menyebutkan bahwa komponen dalam komunikasi antarbudaya terbagi dalam dua kelompok, yakni komponen individu yang terdiri dari motivasi, pengetahuan, sikap, perilaku, dan 
komponen kontekstual (Martin \& wadah di mana interaksi antarbudaya Nakayama, 2007). sangat berpeluang besar untuk terjadi.

Penelitian yang dilakukan oleh Setiap elemen di dalamnya berperan untuk Jannah (2014), di SMA Spins International menciptakan pola komunikasi antarSchool Surabaya oleh menunjukkan bahwa budaya yang tepat dan sesuai terutama siswa di SMA ini memiliki motivasi untuk sebagai pembekalan bagi peserta didik melakukan komunikasi antar-budaya, dalam menghadapi keragaman nasional terutama untuk berteman. Para siswa juga maupun dunia internasional.

memiliki pengetahuan tentang informasi pribadi dan budaya orang yang diajak berkomunikasi. Sementara itu, pada komponen keterampilannya, komunikasi yang efektif di antara siswa tersebut sangat bergantung pada kesamaan bahasa yang digunakan dalam berkomunikasi. Kompetensi yang mereka miliki juga termasuk ketenangan perilaku saat berkomunikasi serta kemampuan bertoleransi dan menghargai perbedaan budaya yang ada.

Selanjutnya, demi mendukung kompetensi para peserta komunikasi antarbudaya, mereka yang terlibat juga harus dapat mengatasi rintangan yang mungkin muncul dalam interaksi antarbudaya mereka. Rahardjo (2005) menyatakan terdapat beberapa faktor yang dapat menghalangi terwujudnya komunikasi antarbudaya yang efektif, di antaranya adalah etnosentrisme, stereotip, dan prasangka.

Dari seluruh komponen yang ada dalam masyarakat, sekolah adalah satu

\section{METODE PENELITIAN}

Penelitian ini dilakukan dengan menerapkan pendekatan kualitatif melalui metode studi kasus. Tujuan kajian kualitatif ialah berfokus pada bagaimana orang atau kelompok orang dapat berbeda 
pandangan dalam memandang suatu realitas, biasanya masalah sosial atau psikologis (Hancock, Ockleford, Windridge, 2009).

Creswell (dikutip dalam Raco, 2010) mendefinisikan studi kasus sebagai suatu eksplorasi dari sistem-sistem yang terkait (bounded system) atau kasus. Suatu kasus menarik untuk diteliti karena corak khas kasus tersebut yang memiliki arti pada orang lain, minimal bagi peneliti.

Teknik penarikan sampel dalam metode kualitatif difokuskan pada pencarian informasi dari kelompokkelompok khusus dan subkelompok dalam populasi (Hancock, 1998).

Penelitian ini dilaksanakan di SMA Sultan Iskandar Muda Medan pada bulan April hingga Juni 2018. Lokasi sekolah ini terletak di Gang Bakul, Desa Sunggal, Medan. Gedung Sekolah Sultan Iskandar Muda berdiri di atas tanah sawah yang sudah tidak bisa dimanfaatkan lagi, dengan luas kurang lebih $1.500 \mathrm{~m}^{2}$ (Sundari, 2017).

Saat ini, Yayasan Perguruan Sultan Iskandar Muda terdiri dari lebih kurang 126 tenaga pengajar lulusan D3, S1, dan S2 dan pegawai dan jumlah siswa berkisar 2.200 orang, 600 orang di antaranya adalah anak asuh yang bebas uang sekolah, anak yang diberikan subsidi silang, beserta penerima

\section{(https://www.vpsim.com/p/anak-asuh-}

\section{bersilang. html)}

Penelitian ini mengambil sampel siswa di SMA Sultan Iskandar Muda, Medan. Siswa yang menjadi informan adalah mereka yang mewakili beberapa etnis yang ada di SMA Sultan Iskandar Muda, Medan antara lain Tionghoa, Batak, Jawa, India, Melayu, dan Minang. Selain itu, sampel juga akan diambil mewakili setiap kelas, yaitu kelas X, XI, dan XII.

Pada tahap pertama pengambilan sampel, peneliti mendapatkan informan sebanyak 18 orang dengan rincian 6 orang setiap tingkatan kelas. Setelah melakukan penyaringan berdasarkan kebutuhan informasi dan data yang didapatkan dari wawancara, serta pertimbangan kriteria yang telah ditetapkan sebelumnya, peneliti menentukan informan sebanyak 9 orang seperti ditunjukkan Tabel 1.

\begin{tabular}{ccc}
\multicolumn{3}{c}{ Tabel 1. Jumlah Informan } \\
\hline No & Kelas & Jumlah Informan \\
1 & X & 3 orang \\
2 & XI & 3 orang \\
3 & XII & 3 orang \\
\hline 4 & Total & 9 orang \\
\hline
\end{tabular}

Sumber: Data penelitian Juni, 2018

Unit analisis penelitian adalah siswa SMA Sultan Iskandar Muda Medan, di mana analisis yang dilakukan adalah terhadap individu (bukan kelompok), yang mengkaji elemen kompetensi komunikasi antarbudaya informan, antara lain; kognitif, afektif, dan perilaku. 
Penelitian ini menggunakan model pada beberapa hal seperti dituangkan yang telah dikembangkan oleh Chen dan dalam tabel berikut.

Starosta. Aspek penelitian akan difokuskan

Tabel 2. Aspek Kompetensi Komunikasi Antarbudaya

\begin{tabular}{lll}
\hline KONSEP & DIMENSI \\
\hline Kompetensi komunikasi & 1. & Proses Kognitif: \\
antarbudaya & a) & Kesadaran diri; diukur dari ada atau tidak rasa sensitif pada respon \\
& dan selalu berusaha menyesuaikan perilaku dengan orang lain. \\
& b) $\begin{array}{l}\text { Kesadaran budaya; diukur dari pemahaman tentang budayanya } \\
\text { sendiri dan orang lain, misalnya nilai-nilai sosial, adat istiadat, } \\
\text { norma dan sistem sosial. }\end{array}$ \\
\hline
\end{tabular}

2. Proses Afektif:

a) Konsep diri; yaitu cara informan memandang dirinya sendiri, apakah memiliki harga diri yang tinggi atau rendah. Informan dengan harga diri yang tinggi mempunyai pemikiran yang baik tentang orang lain serta mudah diterima dalam lingkungannya.

b) Keterbukaan pikiran; yaitu keinginan informan untuk mengekspresikan dirinya serta bersedia menerima pendapat orang lain, mengakui kebutuhan orang lain, serta mengubah pemahaman menjadi tindakan.

c) Tidak menghakimi; informan tidak memiliki prasangka yang dapat mencegah dirinya untuk mendengarkan orang lain dengan tulus dalam proses komunikasi antarbudaya.

d) Relaksasi sosial; kemampuan mengatasi kegelisahan emosi dalam interaksi antarbudaya.

3. Proses perilaku

a) Keterampilan berbahasa; kemampuan untuk meng-gunakan bahasa budaya lain, verbal dan nonverbal.

b) Keterbukaan diri; keinginan untuk membuka diri kepada orang lain.

c) Kefleksibelan tingkah laku; Kemampuan untuk memilih perilaku yang tepat dalam situasi dan konteks yang berbeda.

d) Manajemen interaksi; kemampuan berbicara yang baik dengan individu dari budaya lain.

e) Keterampilan sosial; berkenaan dengan empati dan pemeliharaan identitas.

HASIL DAN PEMBAHASAN

Kompetensi mengaku senang menjalin diskusi dan kecakapan berbagi cerita dengan teman-teman antarbudaya para informan secara kognitif lainnya mengenai berbagai hal yang dapat digambarkan yaitu bagaimana berkenaan dengan kebudayaan, bahasa pengetahuan maupun stereotip yang daerah, cara beribadah, dan hikayatdimiliki oleh para informan terutama hikayat dalam agama mereka. Bahkan di tentang etnis dan agama orang lain. Dari antara informan ada yang bersedia sisi pengetahuan, misalnya, para informan membaca kitab suci agama lain untuk 
mempelajari

dan

memperoleh

pengetahuan mengenai agama tersebut, yaitu Informan 1 yang beretnis India dan beragama Hindu, yang membaca kitab agama Kristen.

Beberapa informan menyatakan ciri khas yang dimiliki oleh teman-temannya yang berlainan etnis dari dirinya. Hal ini dapat digolongkan ke dalam stereotip yang melekat di benak para informan. Misalnya, pernyataan yang muncul dari Informan 2, Informan 3, Informan 5, dan Informan 7 mengenai suku Batak yang identik dengan cara berbicara yang kasar dan kuat. Sebaliknya, etnis Jawa dikenali lemah lembut terutama oleh Informan 5 dan Informan 6.

Sementara itu, meskipun ada pernyataan sebagian informan bahwa semua etnis di sekolah tersebut memiliki kemampuan dan kesempatan yang sama dalam mengejar prestasi (Informan 1 dan Informan 6), sebagian lainnya mengungkapkan bahwa etnis Tionghoa adalah rajin, menonjol di kelasnya, pekerja keras, dan memiliki prinsip hidup yang teguh, seperti pernyataan Informan 2, Informan 5, dan Informan 7.

Pernyataan tersebut dapat kita rujuk kepada Indeks Kebudayaan Nasional (National Culture Index) Hofstede, di mana etnis Tionghoa (Cina) digambarkan dengan indeks maskulinitas yang lebih tinggi dibanding India dan Indonesia. Artinya, sifat kompetitif dan juga anggapan pekerja keras lebih besar dimiliki oleh bangsa ini yakni sebesar 66 .

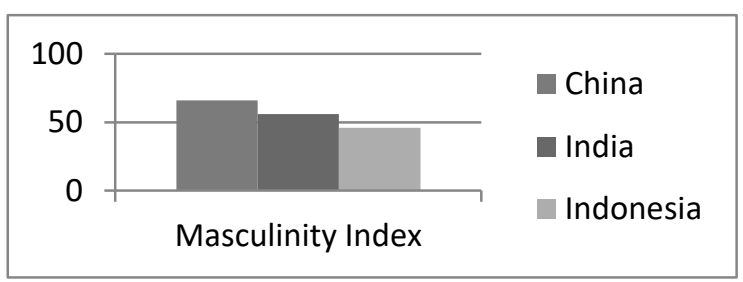

Ganbar 1. Masculinity Index

Sumber: https://www.hofstede-insights.com/ country-comparison/china,india,indonesia/

Selain itu, ternyata didapati prasangka dari Informan 8 yang beretnis India dan beragama Hindu, mengenai kurang adilnya pembagian kekuasaan yang diberikan kepada warga beragama di luar Islam, misalnya Hindu atau Budha yang dianggap minoritas di Medan atau Sumatera Utara. Informan memberikan suatu contoh kasus ketika pendiri Yayasan Perguruan Sultan Iskandar Muda, yaitu dr. Sofyan Tan yang juga salah satu tokoh Tionghoa terpandang di Kota Medan, maju mencalonkan diri sebagai wali kota Medan pada tahun 2010, namun kalah di putaran kedua. Menurut informan, masyarakat tidak memberikan kesempatan kepada etnis minoritas, terutama di luar Islam, untuk memegang kekuasaan.

Pada dimensi afektif, beberapa informan dapat dinilai memiliki konsep diri yang baik, sehingga cukup cakap atau kompeten dalam interaksi antarbudayanya seperti dimiliki oleh Informan 
1 dan 6, sementara ada juga yang masih merasa malu dan canggung untuk membangun komunikasi di antara temanteman baru, seperti dialami oleh Informan

2. Informan 2 ini mengakui lebih mudah berinteraksi dengan lingkungan di sekolahnya terdahulu yang berlatarkan agama yang sama yaitu Islam.

Namun sebaliknya, Informan 6 justru mengakui bahwa lebih mudah berinteraksi di SMA SIM ini ketimbang di sekolah sebelumnya, yang juga berlatarkan mayoritas agama, yaitu Kristen. Menurutnya, sambutan yang diterimanya sebagai siswa baru di SIM lebih hangat dari sekolahnya dulu. Hal unik lainnya yang peneliti temukan, yaitu Informan 4 yang telah bersekolah sejak sekolah dasar di yayasan Sultan Iskandar Muda ini juga masih merasakan kegugupan apabila memulai perkenalan dengan orang-orang baru.

Pada sisi lain, peneliti mendapati bahwa ada kebiasaan di kalangan siswa yang mengarah pada perundungan atau populer dengan istilah bully. Meski sebatas verbal atau kata-kata, para informan menganggap adalah hal yang biasa saja ketika muncul ejekan-ejekan antara sesama mereka berkenaan dengan warna kulit etnis tertentu atau ciri-ciri fisik, bahkan saling ejek nama orang tua.
Kebiasaan dan perilaku semacam ini tentunya berpotensi pada hal negatif seperti menimbulkan depresi pada orang yang mendapatkan perlakuan tersebut secara terus menerus, namun mereka berpikiran kalau hal itu dilakukan dengan kerelaan hati setiap pelaku dan penerimanya. Meski demikian, hal ini justru dapat menunjukkan kepada kita sejauh mana kadar relaksasi sosial yang dimiliki oleh para informan.

Sikap tidak menghakimi juga dimiliki oleh beberapa informan mengenai karakter suku tertentu. Seperti pengalaman Informan 4 yang memiliki teman etnis India yang agak cerewet dan mudah marah, serta informan 5 yang memiliki teman etnis Batak yang pelit, tidak membuat mereka menghakimi semua orang etnis India atau Batak berkarakter demikian. Hal ini sejalan dengan yang diungkapkan oleh semua informan bahwa setiap siswa harus memiliki sikap terbuka dan saling menghargai demi menjaga kebersamaan dan kekompakan di antara para siswa.

Seterusnya, kompetensi atau kecakapan komunikasi antarbudaya para informan baik sisi perilaku, dapat kita lihat beberapa elemen yang muncul seperti keterbukaan diri, manajemen interaksi, dan keterampilan sosial. 
Meskipun menyatakan bahwa setiap orang mesti bersikap terbuka, namun pada dimensi tingkah laku ini ada 2 orang informan yang mengakui bahwa mereka kurang bisa terbuka kepada orang lain, yaitu Informan 2 dan Informan 5.

Seterusnya, pada manajemen interaksinya, peneliti menemukan hal yang menarik dari hubungan di antara siswa di sekolah ini, khususnya para informan. Secara keseluruhan, mereka mampu membangun hubungan baik atau berteman akrab dengan orang-orang yang berbeda etnis dan agama dari dirinya. Siswa etnis Batak beragama Kristen berteman dengan muslim etnis Minang (Informan 6), begitupun etnis Tionghoa beragama Budha berteman dekat dengan etnis dan agama di luar dirinya (Informan 9), dan lain sebagainya.

Hal ini menunjukkan bahwa upaya sekolah membangun keragaman yang dilandasi rasa persaudaraan dapat dikatakan cukup berhasil. Cara yang dibangun oleh sekolah ini misalnya dengan membentuk kelompok tugas yang terdiri dari multietnis dan agama serta mendudukkan siswa berpasang-pasangan berlainan etnis dan agama pula.

Pada elemen keterampilan sosial, informan mampu mengungkapkan kemampuannya berempati, misalnya membantu atau mengunjungi teman yang sakit maupun mengumpulkan donasi dan bantuan bagi korban bencana di sekitarnya, termasuk bersedia menunggui temannya yang lain agama beribadah manakala mereka hendak melakukan aktivitas bersama (Informan 1 dan Informan 6). Selain itu, berkaitan dengan perayaan agama maupun budaya yang sering diselenggarakan oleh sekolah SIM ini, di antara para informan ada yang hanya mendatangi acara agamanya sendiri saja (Informan 2 dan Informan 4), namun ada pula yang berkenan menghadiri perayaan agama lain (Informan 5, Informan 6, Informan 7) bahkan ada yang aktif ikut membantu mendekorasi ruangan serta menjadi pengisi acaranya (Informan $1)$.

Selain berbagai elemen yang dipaparkan di atas, muncul pernyataan yang dapat dianggap menjadi penghalang bagi interaksi antarbudaya yang efektif di sekolah ini. Beberapa informan (Informan 2, Informan 3, dan Informan 5) menyatakan keberatannya apabila siswa etnis Tionghoa menggunakan bahasa etnis mereka sendiri di lingkungan sekolah. Memang telah ada peraturan dari pihak sekolah, yaitu larangan berbahasa etnis tertentu pada saaat jam sekolah, namun hal ini terkadang masih luput diperhatikan. 
Tentunya hal ini dapat menjadi bahan pertimbangan dan rujukan bagi pihak sekolah, untuk lebih memperhatikan berbagai hal yang dapat menjaga kelestarian dan kelangsungan harmoni yang dibangun di SMA Sultan Iskandar Muda ini.

Berdasarkan hasil penelitian dan pembahasan yang telah disajikan, secara detail dapat dilihat bahwa informan yang dapat dikatakan memiliki kompetensi dan kecakapan yang cukup memadai terdapat pada Informan 1 dan Informan 6. Informan 1 adalah siswa laki-laki kelas $\mathrm{X}$ beretnis India dan beragama Hindu, sementara Informan 6 adalah siswa laki-laki kelas XI beretnis Batak dan beragama Kristen. Penilaian ini diberikan berdasarkan berbagai elemen yang terdapat pada keduanya yaitu memiliki pengetahuan, keterbukaan pikiran, relaksasi sosial, serta kemampuan menjalin pertemanan yang cukup baik dengan teman di sekelilingnya.

Lebih jauh, dapat pula kita amati faktor yang mendukung kedua informan mendapatkan kecakapan tersebut. Informan 1 mendapat pengaruh terutama dari orangtua laki-laki dalam berwawasan mengenai agama di luar dirinya sementara Informan 6 sejak awal memang termotivasi bersekolah di SMA Sultan Iskandar Muda untuk mengembangkan pergaulan antar-budayanya.

\section{SIMPULAN}

Tingkat kecakapan paling baik sesuai konsep yang diajukan, ditemukan pada individu yang mempunyai elemen ICC yang paling baik, yaitu Informan 1 dan Informan 6. Kedua informan memiliki kesadaran atau pengetahuan tentang budaya sendiri dan orang lain, konsep diri yang tinggi, keterbukaan pikiran, tidak menghakimi orang lain, serta mampu menampilkan relaksasi sosial, manajemen interaksi, dan keterampilan sosial dalam menjalin interaksi antarbudaya.

Sementara pada individu yang kurang memiliki semua elemen kecakapan, misalnya keterbukaan diri, cenderung merasa agak kesulitan menjalin pertemanan, karena kurangnya rasa percaya diri.

Hal terpenting adalah komunikator mesti memiliki pemahaman mengenai perbedaan antarbudaya, memiliki kemampuan mengatasi rintangan yang ada, serta mau menggunakan keahlian tersebut. Dengan demikian, komunikasi antarbudaya dapat berlangsung dengan baik.

\section{UCAPAN TERIMA KASIH}

Peneliti berterima kasih kepada Lembaga Penelitian dan Pengabdian Masyarakat Universitas Muhammadiyah Sumatera Utara (UMSU) atas hibah 
penelitian internal yang diberikan semasa

peneliti menjadi dosen tetap di lingkungan

UMSU. Terima kasih pula kepada SMA

Sultan Iskandar Muda Medan dan para

informan yang telah memberikan

kesempatan kepada peneliti untuk

melakukan penelitian di sekolah ini.

\section{DAFTAR PUSTAKA}

Chen, G. M. \& Starosta, W. J. (1996). Intercultural Communication Competence. Dalam: B. E. Burelson \& A. W. Kunkel (Eds.), Communication Yearbook 19 (pp. 353 - 383). California: Sage Publications.

Chen, G. M. (2014). Intercultural Communication Competence: a Summary of 30-Year Research and Directions for Future Study. Dalam: Xiaodong, D. \& Guo-Ming Chen (Eds.), Intercultural Communication Competence: Conceptualization and Its Development in Cultural Contexts and Interactions. Newcastle: Cambridge Scholars Publishing.

Collier, M. J. (2015). Intercultural communication competence: Continuing challenges and critical directions.International Journal of Intercultural Relations. 48 (9) 9-11. Diakses dari

https://doi.org/10.1016/i.iiintrel.2015.03.0 $\underline{03}$

Hancock, B. (1998). An Introduction to Qualitative Research. England: Trent Focus Group.

Hancock, B., Ockleford E., Windridge, K. (2009). The NIHR RDS for the East Midlands/ Yorkshire \& the Humber. Diakses dari https://www.rds-vh.nihr.ac.uk/wpcontent/uploads/2013/05/5_Introductionto-qualitative-research-2009.pdf pada 9 April 2019

Hofstede, G. Compare Countries diakses dari https://www.hofstede-insights.com/ country-comparison/china,india, indonesia/ pada 10 Mei 2018

Jannah, N.M. (2014). Kompetensi Komunikasi Antarbudaya di Antara Siswa SMA Spins International School Surabaya. Skripsi. Diakses eprints.upnjatim.ac.id/6096/1/file1.pdf pada 19 Februari 2019

Kealey, D.J. (2015). Some strengths and weaknesses of 25 years of Research on Intercultural Communication Competence: Personal Reflections. International Journal of
Intercultural Relations. 48 (9) 14 - 16. Diakses dari

https://doi.org/10.1016/i.ijintrel.2015.03.0 05 pada 10 April 2019

Koester, J. \& Lustig, M.W. (2015). Intercultural communication competence: Theory, measurement, and application. International Journal of Intercultural Relations. 48 (9) 2021. Diakses dari https://www.sciencedirect.com/ science/article/abs/pii/S014717671500029 $\underline{2}$ pada 9 April 2019

Lieberman, D.A. \& Gamst, G. (2015). Intercultural communication competence revisited: Linking the intercultural and multicultural fields. International Journal of Intercultural Relations, Volume 48, September 2015, Pages 17-19. Diakses dari http://dx.doi.org/10.1016/i.iiintrel.2015.03. $\underline{007}$ pada 10 April 2019

Martin, J.N,. (2015). Revisiting intercultural communication competence: Where to go from here. International Journal of Intercultural Relations. 48 (9) 2015 6-8. Diakses dari

https://doi.org/10.1016/i.ijintrel.2015.03.0 $\underline{08}$ pada 10 April 2019

Martin, J. N. \& Nakayama, T. K. (2007). Intercultural Communication in Contexts. New York: Mcgraw Hill.

Penbek, S., Yurdakul, D. A., \& Cerit, G. (2009). Intercultural Communication Competence: A Study about the Intercultural Sensitivity of University Students Based on Their Education and International Experiences. European and Mediterranean Conference on Information Systems (EMCIS 2009), Crowne Plaza Hotel, Izmir. 13-14 July 2009. Diakses dari http://www.iseing.org/emcis/cdrom $\% 20$ proceedings $\% 20$ refereed $\% 20$ papers/procee dings/presenting\%20papers/c80/c80.pdf

Peng, R-Z. \& Wu, W-P. (2019) Measuring communication patterns and intercultural transformation of international students in cross-cultural adaptation. International Journal of Intercultural Relations, Volume 70 (5) 78-88. Diakses dari https://doi.org/10.1016/i.ijintrel.2019.03.0 04 pada 10 April 2019

Rahardjo, T. (2005). Menghargai Perbedaan Kultural: Mindfulness dalam Komunikasi Antaretnis. Yogyakarta: Pustaka Pelajar.

Sundari, 10 Januari 2017. "Inikah Sekolah Paling Toleran di Indonesia?" Diakses dari majalahkartini.co.id tanggal 20 Januari 2018.

Suharyanto, A. (2015). Dilema Multikulturalisme Pada Masyarakat Multikultur Di Medan, Sumatera Utara. Jurnal Kewarganegaraan: 118-127 
Raco, J.R. (2010). Metode Penelitian Kualitatif: Jenis, Karakteristik, dan Keunggulannya. Jakarta: Grasindo.

Williams, T. R. (2005). Exploring the Impact of Study Abroad on Students" Intercultural Communication Skills: Adaptability and Sensitivity. Journal of Studies in International Education. 9(4) 356 - 371.

Yarosh, M., Lukic, D., Gruber, R. S. (2018). Intercultural competence for students in international joint master programmes. International Journal of Intercultural Relations. 66 (9) 52-72. Diakses dari https://doi.org/10.1016/i.iiintrel.2018.06.0 $\underline{03}$ pada 10 April 2019

Yayasan Perguruan Sultan Iskandar Muda. (2017). Anak Asuh Bersilang. Diakses dari https://www.ypsim.com/p/anak-asuhbersilang. html, pada 27 Juni 2018 